\title{
Pengaruh Penggunaan Limbah Cair Pemindangan Ikan dalam Ransum terhadap Efisiensi Penggunaan Protein Itik Persilangan Mojosari Peking Fase Pertumbuhan
}

\author{
The Effect of Liquid Waste of Steaming Fish in Feed on Protein Efficiency of Mojosari \\ Peking Duck in Growth Phase
}

\author{
F. Yunitasari, L. D. Mahfudz, dan I. Mangisah
}

Departemen Peternakan, Fakultas Peternakan dan Pertanian,Universitas Diponegoro Jalan drh. R. Soejono Koesoemowardojo, Tembalang, Semarang, Kode Pos 50275

Corresponding e-mail : fitriyunitasari73@gmail.com

\begin{abstract}
This study was aimed to examine the effect of liquid waste of shading fish in feed on the protein efficiency of Mojosari Pekin (MP) duck in the growth phase. The research material were 120 Mojosari Pekin ducks at 3 weeks old with average body weight $520.30 \pm 47.82 \mathrm{~g}$. Feed ingredients used were corn, CP 144 concentrate, the liquid waste of shadingfish and rice bran. The study was prepared in complete randomized design (CRD) with 4 treatments and 5 replications. The treatment consisted of T0 (without liquid waste of shading fish), T1 (used $2.5 \%$ of liquid waste of shading fish), T2 (used $5.0 \%$ of liquid waste of steaming fish), and T3 (used $7.5 \%$ of liquid waste of shading fish). Parameters observed were protein consumption, meat protein mass, protein efficiency ratio, and income over feed cost. The data of the research were anallized by analysis of variance with F-test at the 5\% test level, and followed by Duncan's double-area test if there was a significant effect of treatment. The result of variance analysis showed that the use of liquid waste of shading fish in duck feed had no significant effect $(p>0.05)$ on protein consumption and protein efficiency ratio, but it gived significant effect $(\mathrm{p}<0.05)$ on meat protein mass. The largest IOFC was obtained at the T1 treatment. The conclusion of this research is the use of $2.5 \%$ liquid waste of steaming fish can increase the value of meat protein mass and IOFC, so that feed will have more economical.
\end{abstract}

Key words: liquid waste of shading fish, Mojosari Peking duck, and protein efficiency

\begin{abstract}
ABSTRAK
Penelitian ini bertujuan untuk mengkaji pengaruh penggunaan limbah cair pemindangan ikan dalam ransum terhadap efisiensi penggunaan protein itik Mojosari Peking pada fase pertumbuhan. Materi yang digunakan adalah itik Mojosari Peking (MP) jantan berumur 3 minggu sebanyak 120 ekor dengan bobot badan rata-rata $520,30 \pm 47,82 \mathrm{~g}$. Bahan pakan yang digunakan antara lain jagung, bekatul, limbah cair pemindangan ikan (LCPI), dan konsentrat CP 144. Penelitian disusun dalam rancangan acak lengkap (RAL) dengan 4 perlakuan dan 5 ulangan. Perlakuan terdiri dari T0 (pakan tanpa penggunaan limbah cair pemindangan ikan), T1 (penggunaan limbah cair pemindangan ikan 2,5\%), T2 (penggunaan limbah cair pemindangan ikan 5,0\%), dan T3 (penggunaan limbah cair pemindangan ikan 7,5\%). Parameter yang diamati meliputi konsumsi protein, massa protein daging (MPD), rasio efisiensi protein (REP) dan income over feed cost (IOFC). Data hasil penelitian dianalisis ragam dengan uji F pada taraf uji 5\%, kemudian dilanjutkan dengan uji wilayah ganda Duncan apabila terdapat pengaruh perlakuan yang nyata. Hasil analisis ragam menunjukkan bahwa penggunaan limbah cair pemindangan ikan dalam ransum itik MP tidak berpengaruh nyata $(\mathrm{p}>0,05)$ terhadap konsumsi protein, dan REP, tetapi memberikan pengaruh nyata $(\mathrm{p}<0,05)$ terhadap MPD. IOFC terbesar diperoleh pada perlakuan $\mathrm{T}$. Kesimpulan dari penelitian ini adalah penggunaan $2,5 \%$ limbah cair pemindangan ikan dapat meningkatkan nilai meat protein mass dan IOFC sehingga pakan akan lebih bernilai ekonomis.
\end{abstract}

Kata kunci : limbah cair pemindangan ikan, itik persilangan Mojosari Peking, efisiensi penggunaan protein 


\section{PENDAHULUAN}

Suplai daging itik di Indonesia masih rendah. Menurut Ditjennak (2010), itik berperan dalam kontribusi daging sebesar 27.900 ton atau $0,18 \%$ dari total daging unggas. Rendahnya suplai disebabkan karena daging hanya berasal dari itik lokal jantan dan itik betina afkir.

Itik pedaging yang populer dipelihara yaitu itik MP karena produktivitas lebih tinggi dibanding itik lokal, mampu beradaptasi dengan lingkungan, dan masa panen lebih pendek. Itik MP mencapai 1,4 $1,5 \mathrm{~kg}$ dalam 45 - 50 hari pemeliharaan (Andoko dan Sartono, 2013), sedangkan itik Mojosari mencapai bobot badan $1,7 \mathrm{~kg}$ saat umur dewasa (Wakhid, 2010).

Pemeliharaan itik lebih lama dibanding ayam ras menyebabkan biaya pakan meningkat. Itik dipelihara $40-50$ hari sedangkan ayam ras hanya 30 hari. Itik juga mengkonsumsi pakan dengan protein lebih tinggi. Permasalahan tersebut menyebabkan perlunya upaya untuk meminimalisir biaya pakan. Salah satunya dengan penggunaan LCPI sebagai bahan pakan.

Salah satu industri pemindangan ikan di Jawa Tengah yaitu di Desa Bajomulyo, Kec. Juwana, Kab. Pati. Industri tersebut dapat menghasilkan $3.000-5.000$ liter limbah setiap harinya. Limbah dibuang begitu saja sehingga menimbulkan bau menyengat akibat dari pembusukan zat organik.

Kandungan LCPI yaitu air 83,44\%, protein $0,32 \%$, garam $12,08 \%$ dan lemak 10,95\% (Laboratorium Terpadu Undip, 2016). Kadar lemak yang cukup tinggi dimungkinkan berupa Polyunsaturated Fatty Acid (PUFA) atau asam lemak tak jenuh jamak diantaranya omega 3 dan omega 6 . Asam lemak esensial bermanfaat dalam metabolisme, pertumbuhan, komponen struktural dan menambah kelenturan membran sel, memudahkan transport nutrisi serta mengubah komposisi lipoprotein sehingga jumlah protein lebih besar dibandingkan kolesterol. Hal tersebut mempengaruhi fluiditas dari lipoprotein serta meningkatkan aktivitas enzim lipolitik dan villi dalam menyerap nutrisi pakan (Jeromson et al., 2015).

Asam lemak esensial akan mengalami metabolisme intraseluler dan menghasilkan berbagai bentuk omega 3 yaitu asam eikosapentanoat (EPA), dokosaheksanoat (DHA), dan alfa-linolenat (LNA), serta omega 6 berupa asam arakidonat (AA) (Diana, 2012). Bentuk asam lemak esensial inilah yang menjadi komponen struktural dan fungsional dalam membran sel. DHA dikonversi menjadi EPA yang menjadi cikal bakal eicosanoid sebagai respon imun berupa leukotrien dan zat anti inflamasi (anti peradangan).

Imbangan omega 3 dan omega 6 sangat diperlukan dalam pakan karena dapat meningkatkan konsumsi pakan. Apabila konsumsi pakan meningkat maka nutrisi yang diserap untuk sintesis daging lebih banyak sehingga efisiensi penggunaan protein bertambah. Berbagai manfaat tersebut merupakan dasar perlunya penelitian penggunaan LCPI dalam ransum sehingga mampu untuk menambah nilai guna limbah sebagai bahan pakan sumber asam lemak esensial yang akan meningkatkan efisiensi penggunaan protein itik.

Penelitian ini bertujuan untuk mengkaji pengaruh penggunaan LCPI dalam ransum terhadap efisiensi protein itik MP fase pertumbuhan. Manfaat penelitian adalah memberikan informasi dan inovasi baru pemanfaatan LCPI sebagai bahan pakan untuk meningkatkan efisiensi protein itik MP fase pertumbuhan. Hipotesis penelitian ini adalah penggunaan LCPI dalam ransum dapat meningkatkan efisiensi penggunaan protein khususnya konsumsi protein, MPD, REP dan IOFC itik MP fase pertumbuhan.

\section{MATERI DAN METODE}

Penelitian dilakukan di kandang unggas, Fakultas Peternakan dan Pertanian, Universitas Diponegoro, Semarang. Analisis massa protein daging dilakukan di Laboratorium Kimia dan Gizi Pangan, 
Fakultas Peternakan dan Pertanian, Universitas Diponegoro, Semarang.

Materi yang digunakan dalam penelitian yaitu 120 ekor itik MP jantan berumur 3 minggu dengan bobot badan ratarata $520,30 \pm 47,82 \mathrm{~g}$, dibagi secara acak berdasarkan rancangan acak lengkap (RAL) dengan 4 perlakuan dan 5 ulangan, dimana terdapat 6 ekor itik di setiap unit percobaan. Bahan ransum terdiri dari LCPI, jagung, bekatul dan konsentrat CP 144. Kandungan nutrisi bahan penyusun ransum dapat dilihat pada Tabel 1., sedangkan kandungan nutrisi ransum perlakuan tercantum dalam Tabel 2.

LCPI diperoleh dari industri pemindangan di Desa Bajomulyo, Kecamatan Juwana, Kabupaten Pati. Limbah dimasukkan dalam botol kemudian dibawa dengan cooling box dan disimpan dalam lemari pendingin.

\section{Prosedur Penelitian}

Itik berumur $1-15$ hari berada pada brooder. Itik dipindahkan ke petak percobaan pada umur 15 hari, dan mulai perlakuan pada umur 21 hari dengan acuan bobot badan seragam $($ mean \pm SD) setiap petak. Bahan pakan penyusun ransum ditimbang sesuai dengan komposisi. LCPI yang telah ditimbang kemudian dicampur dengan air sesuai dengan rumus :

\section{Penambahan air $(\mathrm{g})$}

$=(0,5 \times$ Berat ransum $)(\mathrm{g})-\mathrm{LCPI}(\mathrm{g})$

Pakan diberikan 2 kali yaitu pukul 06.00 WIB dan 15.00 WIB. Sisa pakan ditimbang pagi hari dan air minum diberikan secara ad libitum. Tahap pengambilan data dilakukan saat itik umur $3-8$ minggu. Adapun cara pengambilan data adalah sebagai berikut:
1. Konsumsi Protein (g), diperoleh dengan rumus Tillman et al. (1998) :

Konsumsi Protein (g)

$=$ Konsumsi pakan $(\mathrm{g}) \times$ Kadar PK ransum $(\mathrm{g})$

$$
\text { Konsumsi Pakan (g) }
$$

$=$ Pemberian pakan $(\mathrm{g})-$ Sisa pakan $(\mathrm{g})$

2. MPD (g), diperoleh dengan rumus Suthama (2003) :

MPD (g) = Kadar Protein Daging Segar (\%) $\times$ Bobot Daging Segar $(g)$

Kadar protein daging diperoleh melalui analisis daging dengan metode mikrokjeldhal. Bobot daging segar diperoleh dari penimbangan daging (tanpa tulang dan kulit) bagian paha dan dada.

3. REP, diperoleh dengan rumus Wahju (1997) :

$\mathrm{REP}=\frac{\text { Pertambahan Bobot Badan }(\mathrm{g})}{\text { Konsumsi Protein }(\mathrm{g})}$

4. IOFC, dihitung dengan rumus :

IOFC $(\mathrm{Rp})=$ Total Pendapatan $(\mathrm{Rp})-$ Pengeluaran Pakan (Rp)

\section{Analisis Data}

Data hasil penelitian dianalisis ragam dengan uji $F$ untuk mengetahui pengaruh perlakuan. Uji wilayah ganda Duncan pada taraf uji 5\% (Steel dan Torrie, 1995) dilakukan saat terdapat pengaruh perlakuan yang nyata. 
Tabel 1. Kandungan nutrisi bahan penyusun ransum (kering udara)

\begin{tabular}{|c|c|c|c|c|c|c|}
\hline Bahan Pakan & EM & PK & SK & LK & $\mathrm{Ca}$ & $\mathrm{P}$ \\
\hline & $(\mathrm{Kkal} / \mathrm{kg})$ & $----\cdot-$ & ----- & $--(\%)-$ & $---\cdot-$ & ---- \\
\hline Limbah cair pemindangan ikan* & $1.705,00^{\mathrm{a}}$ & 0,32 & 0,18 & 10,95 & 0,00 & 0,00 \\
\hline Jagung giling** & $3.321,00^{\mathrm{a}}$ & 8,45 & 8,33 & 3,01 & 0,03 & 0,23 \\
\hline Konsentrat CP $144 * * *$ & $2.500,00$ & 37,00 & 6,00 & 2,00 & 12,00 & 1,20 \\
\hline Bekatul** & $2.887,00^{\mathrm{a}}$ & 12,50 & 16,70 & 14,34 & 0,32 & 1,70 \\
\hline
\end{tabular}

Sumber : *Hasil Analisis Laboratorium Terpadu UNDIP, 2016.

**Hasil Analisis Proksimat Laboratorium Ilmu Nutrisi Pakan, Fakultas Peternakan dan Pertanian, Universitas Diponegoro, 2016.

***Label Kandungan Nutrisi PT. Charoend Phokpand

${ }^{a}$ EM menurut Hartadi, et al. (1980)

Tabel 2. Kandungan nutrisi ransum perlakuan

\begin{tabular}{lrrrr}
\hline \multirow{2}{*}{ Bahan Pakan } & \multicolumn{4}{c}{ Perlakuan } \\
\cline { 2 - 5 } & \multicolumn{1}{c}{ T0 } & \multicolumn{1}{c}{ T1 } & \multicolumn{1}{c}{ T2 } & \multicolumn{1}{c}{ T3 } \\
\hline & $----------------(\%)$ & ------------- \\
Limbah cair pemindangan ikan (\% bobot) & 0,00 & 2,50 & 5,00 & 7,50 \\
Jagung & 49,00 & 46,50 & 44,00 & 40,50 \\
Bekatul & 20,00 & 20,00 & 20,00 & 20,00 \\
Konsentrat CP 144 & 31,00 & 31,00 & 31,00 & 32,00 \\
Total & 100,00 & 100,00 & 100,00 & 100,00 \\
\hline Kandungan Nutrisi & & & & \\
\hline Energi Metabolis (EM) (Kkal/kg) & $2.979,69$ & $2.939,29$ & $2.898,89$ & $2.850,28$ \\
Protein Kasar (PK) (\%) & 18,11 & 17,91 & 17,70 & 17,79 \\
Serat Kasar (SK) (\%) & 9,28 & 10,01 & 9,65 & 9,16 \\
Lemak Kasar (SK) (\%) & 4,96 & 5,16 & 5,36 & 5,55 \\
Kalsium (Ca) (\%) & 3,80 & 3,80 & 3,80 & 3,92 \\
Fosfor (P) (\%) & 0,82 & 0,82 & 0,81 & 0,82 \\
\hline
\end{tabular}

\section{HASIL DAN PEMBAHASAN}

Hasil penelitian efisiensi penggunaan protein itik MP umur 8 minggu dengan perlakuan penggunaan LCPI dalam ransum dapat dilihat pada Tabel 3.

\section{Konsumsi Protein}

Hasil analisis ragam menunjukkan bahwa penggunaan LCPI dalam ransum tidak memberikan pengaruh nyata $(\mathrm{P}>0,05)$ terhadap konsumsi protein itik MP. Tidak adanya pengaruh nyata pada konsumsi protein disebabkan kadar protein kasar ransum yang diberikan sama, sehingga tidak mempengaruhi konsumsi protein. Menurut Herdiana et al. (2014), kadar energi metabolis dan protein pakan berpengaruh pada konsumsi protein.
Tabel 3. menunjukkan rataan konsumsi protein itik MP umur $3-8$ minggu hasil penelitian berkisar 23,90-24,19 g/ekor/hari. Hasil tersebut lebih tinggi dibandingkan penelitian Widianto et al. (2015) bahwa ratarata konsumsi protein itik Hibrida (persilangan Mojosari dan Peking) dengan penambahan tepung buah mengkudu selama 40 hari adalah 17,97 g/ekor/hari.

Konsumsi protein sangat berkaitan dengan konsumsi ransum dimana dalam penelitian ini menunjukkan hasil yang tidak berpengaruh nyata $(\mathrm{P}>0,05)$. Hal ini berarti penggunaan LCPI sampai taraf 7,5\% dalam ransum memberikan tingkat palatabilitas yang sama dengan ransum kontrol. Semakin besar konsumsi ransum maka semakin besar pula konsumsi protein. Hal ini sesuai dengan pendapat Wahju (1997) yang menyatakan bahwa jumlah konsumsi pakan akan 
mencerminkan besarnya konsumsi protein. Menurut Mahfudz (2006), konsumsi protein merupakan jumlah protein pakan yang masuk ke dalam tubuh dan diperoleh dari perkalian antara konsumsi ransum dengan kandungan protein ransum.

Penggunaan 7,5\% LCPI dalam ransum masih sedikit sehingga belum mampu meningkatkan konsumsi protein itik MP. Hal ini terjadi karena kandungan omega 3 dalam limbah masih rendah yakni $<0,1 \%$ dengan bahan kering $16 \%$ sehingga kandungan omega 3 dalam ransum T3 hanya $0,0012 \%$. Iriyanti et al. (2005) menyatakan konsumsi pakan dipengaruhi oleh perbedaan komposisi asam lemak, kombinasi minyak ikan lemuru dan sawit 4\% menunjukkan peningkatan konsumsi ransum karena imbangan asam lemak sehingga ransum lebih palatable dibandingkan ransum kontrol dengan kandungan lemak yang rendah (3,6\%). Menurut Newton (1996) yang dikutip oleh Wijiastuti et al. (2013), imbangan omega 3 dan omega 6 sebaiknya bernilai 5: 1 agar fungsi fisiologis tubuh berjalan sempurna.

\section{Massa Protein Daging}

Hasil analisis ragam menunjukkan penggunaan LCPI dalam ransum berpengaruh nyata $(\mathrm{P}>0,05)$ terhadap MPD itik MP fase pertumbuhan. MPD merupakan tolok ukur deposisi protein daging, sehingga semakin tinggi nilainya maka kualitas daging semakin baik. Sari et al. (2014) menyatakan MPD menjadi indikator keberhasilan pemanfaatan protein ke dalam jaringan, sehingga semakin tinggi kandungan protein daging maka semakin baik untuk unggas.

Penggunaan LCPI pada taraf 2,5\% dalam ransum dapat meningkatkan secara signifikan $(\mathrm{P}<0,05)$ MPD. Tingginya MPD merupakan pengaruh dari kandungan asam lemak esensial dalam LCPI. Catala (2013) menyatakan PUFA mengandung asam lemak esensial omega 3 dan omega 6 untuk membantu pembentukan sel, melenturkan membran sel, mempermudah penyerapan nutrisi, membangun jaringan tubuh, serta meningkatkan metabolisme. Asam lemak esensial memudahkan transport nutrisi karena melenturkan membran sel dan mengubah komposisi lipoprotein sehingga jumlah protein lebih besar dibanding kolesterol. Hal tersebut mempengaruhi fluiditas lipoprotein serta meningkatkan aktivitas enzim lipolitik dan villi dalam mengabsorbsi nutrisi khususnya protein.

Omega 3 yang dikonsumsi itik mempengaruhi metabolisme dalam sel khususnya protein karena menghasilkan efek antiperadangan. Mozaffarian dan $\mathrm{Wu}$ (2011) menyatakan bahwa penggabungan omega 3 ke membran sel dengan perubahan fungsi protein dan persinyalan, selanjutnya dapat berkontribusi pada mekanisme antiinflamasi. Omega 3 sebagai zat antiinflamasi dapat mencegah peradangan sehingga tidak terjadi kerusakan sel. Menurut Smith et al. (2011), suplementasi omega 3 dapat mencegah hilangnya massa otot pada hewan serta mempengaruhi sintesis protein.

Tabel 3. Pengaruh penggunaan limbah cair pemindangan ikan terhadap efisiensi penggunaan protein itik Mojosari Peking fase pertumbuhan

\begin{tabular}{lrrrr}
\hline \multirow{2}{*}{ Parameter } & \multicolumn{4}{c}{ Perlakuan } \\
\cline { 2 - 5 } \multicolumn{1}{c}{ T0 $(0 \%)$} & $\mathrm{T} 1(2,5 \%)$ & $\mathrm{T} 2(5 \%)$ & $\mathrm{T} 3(7,5 \%)$ \\
\hline Konsumsi protein (g) & 24,08 & 24,19 & 23,90 & 24,07 \\
MPD bagian paha dan dada (g) & $52,63^{\mathrm{ab}}$ & $56,79^{\mathrm{a}}$ & $49,02^{\mathrm{b}}$ & $49,67^{\mathrm{b}}$ \\
REP & 1,16 & 1,23 & 1,12 & 0,98 \\
IOFC (Rp) & $4.592,44$ & $6.129,25$ & $4.357,20$ & $2.205,09$ \\
\hline
\end{tabular}

Keterangan : Superskrip berbeda nyata pada baris yang sama menunjukkan perbedaan yang nyata $(\mathrm{P}<0,05)$ 
Penggunaan LCPI 5\% ke atas dapat menurunkan dengan nyata $(\mathrm{P}<0,05)$ MPD. Hal ini terjadi karena kandungan garam ransum T2 dan T3 lebih tinggi sehingga menurunkan produktivitas itik. Kadar garam LCPI mencapai $12,08 \%$, sehingga apabila BK limbah $16 \%$ berarti BK non garam hanya 4,72\%. Kadar garam dalam ransum T1, T2, dan T3 berturut-turut adalah $0,3 \% ; 0,6 \%$ dan $0,9 \%$. Kadar garam ini melebihi batasan garam yang dianjurkan dalam pakan itik. Wakhid (2010) menyatakan kandungan garam ransum yang tinggi, mengakibatkan keracunan garam sehingga fungsi jaringan menurun dan konsumsi air lebih tinggi.

Faktor lain penyebab penurunan MPD yaitu kadar kalsium $(\mathrm{Ca})$ daging semakin meningkat pada T2 dan T3. Hasil penelitian Fahrizal (2017) melaporkan bahwa massa Ca daging $\mathrm{T} 0, \mathrm{~T} 1, \mathrm{~T} 2$, dan $\mathrm{T} 3$ berturut-turut adalah 2,018 ; 2,149 ; 3,449 dan 3,496 $\mathrm{mg} / 100 \mathrm{~g}$. MPD berbanding terbalik dengan massa $\mathrm{Ca}$ daging. Peningkatan $\mathrm{Ca}$ merupakan akibat dari kandungan lemak pada LCPI mempermudah penyerapan dan kelarutan vitamin khususnya A, D, E, dan K. Vitamin $\mathrm{D}$ dalam pakan akan larut dan terserap sehingga mempengaruhi deposisi protein dan kalsium. Yusmiati dan Wulandari (2017) menyatakan vitamin D dapat meningkatkan penyerapan $\mathrm{Ca}$ pada duodenum dengan merangsang produksi protein pengikat $\mathrm{Ca}$ (Ca Binding Protein). Apabila vitamin D yang diserap tinggi maka penyerapan $\mathrm{Ca}$ menjadi lebih besar.

Deposisi protein dalam sel dipengaruhi oleh Ca. Apabila Ca dalam sel berbentuk ion bebas maka akan memicu aktivasi enzim proteolisis. Menurut Syafitri et al. (2015), kelebihan $\mathrm{Ca}$ dalam bentuk ion bebas menyebabkan aktivasi enzim CANP (Calsium Activated Neutral Protease) yaitu enzim degradasi protein. Semakin besar massa kalsium daging, maka akan terjadi penurunan massa protein daging. Sebenarnya keberadaan ion $\mathrm{Ca}$ juga dibutuhkan untuk aktivasi CANP, namun apabila degradasi protein melebihi ukuran sintesis protein maka menyebabkan protein daging dan pertumbuhan menurun.

\section{Rasio Efisiensi Protein}

Hasil analisis ragam menunjukkan penggunaan LCPI dalam ransum tidak berpengaruh nyata $(\mathrm{P}>0,05)$ terhadap REP. Tidak adanya pengaruh nyata pada REP disebabkan oleh konsumsi protein dan pertambahan bobot badan (PBB) sama. Hal tersebut menunjukkan bahwa kualitas protein yang dikonsumsi sama. Penggunaan LCPI sebesar 2,5\% dalam ransum menunjukkan hasil REP yang paling tinggi dibandingkan perlakuan lain.

Penyebab penurunan REP yaitu penggunaan LCPI 5\% ke atas menyebabkan produktivitas menurun karena kadar garam ransum T2 dan T3 terlalu tinggi dan tidak dapat ditoleransi oleh itik. Nilai rata-rata REP penelitian ini berkisar $0,98-1,23$, hasil tersebut lebih rendah dibandingkan dengan penelitian Herdiana et al. (2014) yang menunjukkan nilai REP pada itik lokal jantan umur 8 minggu akibat penggunaan ampas kecap dalam pakan yang mengandung PK $19 \%$ dan EM $2.900 \mathrm{kkal} / \mathrm{kg}$ berkisar antara $1,31-1,35$. REP yang rendah mengindikasikan bahwa protein yang dikonsumsi tidak efisien. Menurut Anggorodi (1994), semakin tinggi nilai REP maka penggunaan protein pakan yang dikonsumsi semakin efisien.

Penurunan nilai REP disebabkan karena pertambahan bobot badan dan konsumsi protein itik MP setiap perlakuan semakin menurun. Sari et al. (2014) menyatakan nilai REP dipengaruhi oleh beberapa faktor yaitu besarnya pertambahan bobot badan, konsumsi ransum, serta imbangan protein dan energi dalam ransum. Menurut Wahju (1997), REP juga dipengaruhi oleh umur dan jenis kelamin, jenis kelamin jantan memiliki pertambahan bobot badan yang lebih tinggi dibandingkan betina sehingga nilai REP lebih tinggi.

\section{Income over Feed Cost (IOFC)}

Berdasarkan rata-rata hasil

perhitungan menunjukkan bahwa semakin tinggi level penggunaan LCPI memberikan penurunan pada nilai IOFC untuk T2 dan T3 $(>2,5 \%)$ namun meningkat pada perlakuan 
T1 (2,5\%). Perlakuan T1 menghasilkan nilai IOFC paling tinggi. Hal ini menunjukkan bahwa penggunaan LCPI yang optimal pada penelitian ini adalah taraf 2,5\%. Peningkatan nilai IOFC disebabkan karena harga LCPI murah sehingga biaya pakan dapat ditekan.

Meskipun penggunaan LCPI dapat menekan biaya pakan, namun penggunaan melebihi taraf $2,5 \%$ menghasilkan pertambahan bobot badan yang rendah sehingga nilai IOFC menurun. Menurut Christian et al. (2016), faktor yang mempengaruhi nilai IOFC yaitu bobot badan ternak, biaya pakan dan konversi pakan.

T1 menghasilkan pertambahan bobot badan yang paling tinggi dengan konsumsi pakan yang relatif sama dibandingkan perlakuan lain, sehingga pendapatan penjualan itik lebih tinggi. IOFC itik MP pada T1 sebesar Rp. 6.129,25/ekor dengan PBB 29,69 g/ekor/hari, lebih tinggi dari penelitian Nurhakim dan Akbar (2014) bahwa IOFC pemeliharaan itik dikandang panggung lebih besar dibandingkan dengan itik dikandang postal yaitu income over feed cost Rp. 3.219.400, dengan PBB 25,55 $\mathrm{g} / \mathrm{ekor} / \mathrm{hari}$ dan rataan feed conversion ratio sebesar 2,60. Harga pakan, konsumsi ransum, bobot akhir dan harga itik merupakan faktor yang mempengaruhi harga jual. Semakin tinggi bobot itik dan harga pasar, maka nilai IOFC semakin meningkat.

Pertambahan bobot badan T2 dan T3 mengalami penurunan dibandingkan $\mathrm{T} 1$ dikarenakan itik tidak dapat mentolerir kandungan garam yang terdapat dalam ransum sehingga mengalami keracunan garam. Wakhid (2010) menyatakan bahwa kandungan garam yang berlebihan dalam ransum mengakibatkan keracunan garam.

\section{KESIMPULAN}

Penggunaan LCPI hingga taraf 2,5\% dalam ransum itik persilangan Mojosari Peking umur 8 minggu dapat meningkatkan MPD. Penggunaan LCPI yang paling baik yaitu pada taraf $2,5 \%$ karena menghasilkan efisiensi penggunaan protein dan keuntungan terbaik.

Penggunaan LCPI dalam ransum itik fase pertumbuhan tidak boleh melebihi 2,5\% agar menghasilkan produktivitas yang optimal. Apabila dilakukan penelitian lanjutan, kadar garam perlu diturunkan agar level penggunaan limbah dapat ditingkatkan.

\section{DAFTAR PUSTAKA}

Andoko, A. dan Sartono. 2013. Beternak Itik Pedaging. AgroMedia Pustaka, Jakarta.

Anggorodi, H. R. 1994. Ilmu Makanan Ternak Unggas. Cetakan ke-5. PT. Gramedia Pustaka Utama, Jakarta.

Catala, A. 2013. Five decades with polyunsaturated fatty acids : chemical synthesis, enzymatic formation, lipid peroxidation and its biological effects. J. Lipids. 1 (1) : 1 - 20.

Christian, I. H. Djunaidi dan M. H. Natsir. 2016. Pengaruh penambahan tepung kemangi (Ocimum basilicum) sebagai aditif pakan terhadap penampilan produksi itik pedaging. J. Ternak Tropika. 17 (2): 34-41.

Diana, F. M. 2012. Omega 3. J. Kesehatan Masyarakat. 6 (2) : $113-117$.

Direktorat Jenderal Peternakan. 2010. Statistik Peternakan dan Kesehatan Hewan. Dirjen Bina Produksi Peternakan, CV. Karya Cemerlang, Deptan RI, Jakarta.

Hartadi, H., S. Reksodiprodjo, S. Lebdosukojo, dan A. D. Tillman. 1980. Tabel-Tabel dari Komposisi Makanan Ternak untuk Indonesia. International Feedstuffs Institute, Logan, Utah.

Herdiana, R. M., Y. Marshal, R. Dewanti, dan Sudiyono. Pengaruh penggunaan ampas kecap dalam pakan terhadap pertambahan bobot badan harian konversi pakan, rasio efisisensi protein, dan produksi karkas itik lokal jantan 
umur delapan minggu. J. Buletin Peternakan. 38 (3) : $157-162$.

Iriyanti, N., T. Yuwanta, Zuprizal dan S. Keman. 2005. Pengaruh penggunaan asam lemak rantai panjang dalam pakan terhadap penampilan dan profil lemak darah serta gambaran ovarium ayam kampung betina. J. Buletin Peternakan. 29 (4) : 177 - 184.

Jeromson, S., I. J. Gallagher, S. D. R. Galloway and D. L. Hamilton. 2015. Omega-3 fatty acids and skeletal muscle health. J. Mar. Drugs. 13. 6977 -7004 .

Mahfudz, L. D. 2006. Pengaruh penggunaan ampas tahu fermentasi terhadap efisiensi penggunaan protein itik tegal jantan. J. Indon. Trop. Anim. Agric. 31 (2) : $129-134$.

Mozaffarian, D. and J. H. Y. Wu. 2011. Omega-3 fatty acids and cardiovascular disease. J. American College of Cardiology. 58 (20) : 2047 - 2067.

Newton, I. S. 1996. Food encrichment with long-chain n-3 PUFA. INFORM 7 : $169-171$.

Nurhakim dan M. Akbar. 2014. Analisis pertambahan bobot badan (PBB) dan feed conversion ratio (FCR) serta income over feed cost (IOFC) pada usaha itik jantan lokal. J. E-student. 3 (1) $: 1-5$.

Sari, K. A., B. Sukamto, dan B. Dwiloka. 2014. Efisiensi penggunaan protein pada ayam broiler dengan pemberian pakan mengandung tepung daun kayambang (Salvinia molesta). J. Agripet. 14 (2) : $76-83$.

Smith, G. I., P. Atherton, D. N. Reeds, B. S. Mohammed, D. Rankin, M. J. Rennie, and B. Mittendorfer. 2011. Dietary omega-3 fatty acid supplementation increases the rate of muscle protein synthesis in older adults : a randomizes controlled trial ${ }^{1-3}$. J. Am. Clin. Nutr. $93: 402-412$

Steel, R. G. D, dan J. H Torrie.1995. Prinsip dan Prosedur Statistika suatu Pendekatan Biomatrik. Cetakan kedua. PT. Gramedia Pustaka Utama, Jakarta.

Suthama, N. 2003. Metabolisme protein pada ayam kampung periode pertumbuhan yang diberi ransum memakai dedak padi fermentasi. J. Pengemb. Pet. Trop : 44-48.

Syafitri, Y. E., V. D. Yunianto, dan N. Suthama. 2015. Pemberian ekstrak daun beluntas (Pluchea indica Less) dan klorin terhadap massa kalsium dan massa protein daging pada ayam broiler. J. Anim. Agric. 4 (1) : 155 164.

Tillman, A. D., H. Hartadi, S. Reksohadoprojo, S. Prawirokusumo, dan L. Soekojo. 1998. Ilmu Makanan Ternak Dasar. Gadjah Mada University Press, Yogyakarta.

Wahyu, J. 1997. Nutrisi Unggas. Gadjah Mada University Press, Yogyakarta.

Wakhid, A. 2013. Beternak Itik. PT. Agromedia Pustaka, Jakarta.

Widianto, B., H. S. Prayogi dan Nuryadi. 2015. Pengaruh penambahan tepung buah mengkudu (Morinda citrifolia L.) dalam pakan terhadap penampian produksi itik Hibrida. J. Ilmu-Ilmu Peternakan. 25 (2) : $28-35$.

Wijiastuti, T. E. Yuwono, dan N. Iriyanti. 2013. Pengaruh pemberian minyak ikan lemuru terhadap total protein plasma dan kadar hemoglobin (HB) pada ayam kampung. J. Ilmiah Peternakan. 1 (1) : $228-235$.

Yusmiati, S. N. H. dan R. E. Wulandari. 2017. Pemeriksaan kadar kalsium pada masyarakat dengan pola makan vegetarian. J. Sain Health. 1 (1) : $43-$ 49. 